\title{
Analgesic, Antidiarrheal and Antidepressant Activities of Anethum sowa Linn. in Swiss-Albino Mice Model
}

\author{
Muhammad Abdullah Al-Mansur ${ }^{1}$, M. Mahboob Ali Siddiqi ${ }^{2}$ and Koushik Saha ${ }^{3}$ \\ ${ }^{1}$ Institute of National Analytical Research and Services (INARS), BCSIR, Dhaka-1205, Bangladesh \\ ${ }^{2}$ Institute of Natural Sciences, United International University, Dhaka-1209, Bangladesh \\ ${ }^{3}$ Department of Chemistry, Jahangirnagar University, Savar, Dhaka-1342, Bangladesh
}

(Received: July 17, 2017; Accepted: October 08, 2017; Published: January 30, 2018)

\begin{abstract}
The hexane (HE), dichloromethane (DCME), ethyl acetate (EAE) and methanol (ME) extracts of seed and stem of Anethum sowa were subjected to screenings for analgesic, anti-diarrheal and anti-depressant activities. The peripheral and central analgesic actions were determined by using formalin-induced writhing test and tail immersion method. The DCME extract of stem, at a dose of $200 \mathrm{mg} / \mathrm{kg}$ body weight, significantly reduced the number of writhing movements whereas the methanol extract of seed at the same dose exhibited remarkable analgesic activity in tail immersion method. In castor oil induced anti-diarrheal assay, the ethyl acetate extract of stem, at $400 \mathrm{mg} / \mathrm{kg}$ body weight, exhibited significant anti-diarrheal effect. In addition, significant anti-depressant activity was observed at a dose of 400 $\mathrm{mg} / \mathrm{kg}$ body weight as compared to the standard drug in case of HE extract of stem.
\end{abstract}

Key words: Anethum sowa L., analgesic, antidiarrheal, antidepressant.

\section{Introduction}

Research on Medical Anthropology firmly demonstrated the magnificent contribution of plantbased medicine in curing diseases and prolonging lives parallel to those of conventional medicines. For thousands of years, many people prefer to use nonconventional medicine as a relaxing alternative or as complementary to the conventional method of treatment since plant is the greater source of bioactive natural compounds. In addition, Bangladesh is a good repository of medicinal plants belonging to various families. This is why, appropriate scientific probe are essential to explore for the discovery and development of newer and safer drug candidates for treating diverse diseases (Banglapedia, 2012 and Ashraf et al., 2014).

An unpleasant sensation that can range from mild, localized discomfort to agony. Pain has both physical and emotional components. The physical part of pain results from nerve stimulation. Pain may be contained to a discrete area, as in an injury, or it can be more diffuse, as in disorders like fibromyalgia. Pain is mediated by specific nerve fibers that carry the pain impulses to the brain where their conscious appreciation may be modified by many factors. Analgesic agents retard or eliminate algesia or pain by acting on the sensory nervous system without significantly altering consciousness. Synthetic drugs cause multiple unwanted effects including gastrointestinal discomfort, ulcers, bleeding etc. A variety of drugs are commonly found like nonsteroidal anti-inflammatory drugs (NSAIDs), opioids etc. for removal of pain but these are not completely free from side effects (Su et al., 2012; Yu et al., 2012).

Diarrhoea results from an imbalance between the absorptive and secretory mechanisms in the intestinal tract, resulting in an excess loss of fluid in the faeces. In some diarrhoeas, the secretory component predominants, while other diarrhoeas are characterized by hypermotility (Zubair et al., 2015). There are some drugs currently used for treating

Correspondence to: Muhammad Abdullah Al-Mansur; E-mail: nayeembcsir@ gmail.com; Tel: +88-01715010829 
diarrhea but new agents are still required for improved treatment (Li et al., 2013; Zavala-Mendoza et al., 2013). In order to provide patient's safety and comfort regarding pain and diarrhea, plants might serve important sources of medicinal agents.

Depression is a chronic ailment that can impact on people of all ages. Although there are many potent antidepressants available today, the current armamentarium of therapy is often not sufficient, with unsatisfactory results in about one-third of all subjects treated. This delivers impulsion to the search of newer and more potent antidepressants (Shastry et al., 2017).

Anethum sowa Linn. (Common name- Dill; Bengali- Shulfa; Family-Apiaceae), is an annual or a biennial cold weather glabrous and aromatic herb. In Bangladesh it is abundantly cultivated in the northern part of the country and throughout India mainly in Punjab, Uttar Pradesh, Gujarat, Maharasshtra, Assam and West Bengal. It is often found with weed of cultivation and even as an escape in irrigated fields. Its seed is used as insecticidal, ovicidal and has synergistic activity of dillapiol and also contains essential oil having antioxidant, antimicrobial activity (Al-Mansur et al., 2016).

There are very few reports that describe the scientific justification supporting the traditional use of seed and stem of A. Sowa. That is why, the present study was undertaken in the investigation of the analgesic, anti-diarrheal and antidepressant activities using in vitro and in vivo models.

\section{Materials and Methods}

Plant collection, identification and authentification: Fresh stem and seed of A. sowa were collected from BCSIR campus, Dhaka and identified by the taxonomist of Bangladesh National Herbarium, Dhaka, where a voucher specimen (No. = 31282) has been deposited (Al-Mansur et al., 2016).

Extraction and processing: Freshly collected stem and seeds of A. sowa were dried in open air and powdered by using a grinding machine. The air-dried and powdered material of seed $(250 \mathrm{gm})$ was soaked in ethyl acetate (2.5 litres $\times 3)$ at room temperature for 2 days against each soaking. Consequently gummy mass of ethyl acetate extract (2.01 gm) was obtained from the filtrate using rotary evaporator under reduced pressure. By the same process, $250 \mathrm{gm}$ of powdered stem was soaked in ethyl acetate (2.5 litres $\times 3$ ) at room temperature for 2 days for each soaking. Consequently, gummy mass of ethyl acetate extract (1.45 gm) was separated by filtration followed by evaporation of solvent using rotary evaporator under reduced pressure (Al-Mansur et al., 2016).

The HE, DCME, EAE and ME extract of seed and stem of $A$. sowa were subjected to screenings for analgesic, anti-diarrheal and anti-depressant activities.

Animals: Swiss-albino mice of either sex, aged 4-5 weeks and weighing between 23-25 gm obtained from the Animal Resources Branch of the International Centre for Diarrhoeal Diseases and Research, Bangladesh (ICDDR,B) were used for the experiment. All the animals were acclimatized for one week prior to the experiments. The animals were housed under standard laboratory conditions (relative humidity $55-65 \%$, room temperature $25.0 \pm 20^{\circ} \mathrm{C}$, and $12 \mathrm{~h}$ light dark cycle) and fed with icddr,B formulated standard diet and had free access to tap water but were fasted $12 \mathrm{~h}$ prior to each experiment. The Federation of European Laboratory Animal Science Associations (FELASA) guidelines and recommendations were followed to reduce the pain and stress of the experimental mice.

Drugs: Drugs used in this study include Diclofenac sodium (Square Pharmaceuticals Ltd., Bangladesh), Tramadol (Beximco Pharmaceuticals Ltd., Bangladesh) and Loperamide (OpsoninPharma Ltd., Bangladesh).

Formalin induced method: Peripheral analgesic activity can be evaluated by formalin test (Aliet al., 2010). Mice were divided into 4 groups of 3 mice in each group. The control group received $1 \%$ Tween 80 in normal saline $(10 \mathrm{ml} / \mathrm{kg}$ body weight $)$, the standard group received Diclofenac $\mathrm{Na}(50 \mathrm{mg} / \mathrm{kg}$ b.w.) and the experimental groups received crude extract of 200 and $400 \mathrm{mg} / \mathrm{kg}$ b.w. 30 minutes later each mouse was injected with $1 \%$ formalin at a dose of $10 \mathrm{ml} / \mathrm{kg}$ b.w. 
The number of writhing responses was recorded for each animal during a subsequent 5 min period after 10 min of intraperitoneal administration of Formalin and the mean writhings for each group was obtained.

Tail immersion test: The tail immersion method was used to evaluate the central analgesic activity (Aydin et al., 1999; Kaushik et al., 2012).Again the mice were equally divided into 4 groups. The control group received $1 \%$ Tween 80 in normal saline (20 $\mathrm{ml} / \mathrm{kg}$ b.w.), the standard group received Diazepam $(1 \mathrm{mg} / \mathrm{kg}$ b.w.) and the experimental groups received crude extract of 200 and $400 \mathrm{mg} / \mathrm{kg}$ b.w. The lower $1-2 \mathrm{~cm}$ portion of the tail was marked and immersed in warm water $\left(55 \pm 2{ }^{\circ} \mathrm{C}\right)$. Within a few seconds, the mice were seen to react by withdrawing the tail and the reaction time was recorded by a stop watch. The experimental reaction time was determined periodically at $0,30,60$ and 90 minutes after the oral administration of the test substances. The cut-off time for tail immersion latency was set at 15 seconds. The reaction time was also determined prior to the administration of any substances.

Antidiarrheal activity: Anti-diarrheal activity was evaluated by using castor oil induced method in mice (Agbor et al., 2014; Sebai et al., 2014). Sixteen Swiss albino mice were randomly divided into four groups $(n=4)$. Control group received $1 \%$ Tween 80 in normal saline of $10 \mathrm{ml} / \mathrm{kg}$ of b.w., standard group received Loperamide $50 \mathrm{mg} / \mathrm{kg}$ b.w. as standard drug and the test groups received the extract at the doses of 200 and $400 \mathrm{mg} / \mathrm{kg}$ b.w. Mice were housed in separate cages with paper lining at the bottom for collection of fecal matters. Diarrhea was induced in the mice by oral administration of castor oil (1 $\mathrm{ml} /$ mice). Extract and drugs were given orally 1 hour before administration of castor oil. During an observation period of 5 hours, the total number of fecal output by the animals was recorded.

Anti-depressant activity: Thiopental sodium induced sleeping time test was carried out according to the method of Williamson et al. (1996).The test animals were divided into three groups consisting of three mice per group. Group I was the control group whereas group III was experimental group. The experimental group was administered with test samples prepared with normal saline water and Tween-80 at doses of $400 \mathrm{mg} / \mathrm{kg}$ body weight, while the positive control group was treated with diazepam $(1 \mathrm{mg} / \mathrm{kg}$ ) and control with normal saline water containing $1 \%$ Tween 80 in solution. Thirty minutes later, thiopental sodium (40 $\mathrm{mg} / \mathrm{kg}$ b.w.) was administered intraperitonially to all the groups to induce sleep. The onset of sleep and total sleeping time were recorded for both control and treated groups.

\section{Results and Discussion}

The HE, DCME, EAE and ME extracts of $A$. sowa were subjected to assay for analgesic and antidiarrheal activities at doses of 200 and $400 \mathrm{mg} / \mathrm{kg}$ b.w and anti-depressant activity at $400 \mathrm{mg} / \mathrm{kg}$ b.w.

In formalin induced writhing test, the DCME of stem at a dose of $200 \mathrm{mg} / \mathrm{kg}$ b.w significantly reduced the number of writhing movements due to the intraperitoneal administration of formalin. The dose-dependent reaction time in second (Table 1) of abdominal constrictions by the DCME extract indicates antinociceptive potential of the plant. Prostaglandin causes pain. It can be assumed that this plant extract might inhibit either the biosynthetic pathway of prostaglandin production or the binding of prostanoids to their receptors. The DCME extract may also be responsible for inhibiting the production of neuronal mediators (Duarte et al., 1988; Sikder et al., 2013).

The methanol extract of seeds exhibited significant analgesic activity in tail immersion method as supported by the increase in latency period when compared to control. The augment in latency period was obtained to be dose dependent. However, maximum effect was seen at the dose of $200 \mathrm{mg} / \mathrm{kg}$ b.w. and was comparable with the standard drug. 
Castor oil induced diarrhoeal model is a practical approach since the autacoids and prostaglandins are involved to make diarrhoea in human (Horton et al., 1968; Greenbargena et al., 1978). The liberation of ricinolic acid from castor oil causes irritation and imflammation of the intestinal mucosa, resulting in release of prostaglandins, which stimulate motility and secretion (Pierce et al., 1971).

Table 1. Peripheral analgesic activity of $A$. sowa by formalin-induced method.

\begin{tabular}{lcccc}
\hline \multirow{2}{*}{ Sample } & \multicolumn{4}{c}{ Analgesic activity (reaction time in second) } \\
\cline { 2 - 5 } & \multicolumn{2}{c}{ A. sowa L. stem extract } & \multicolumn{2}{c}{ A. sowa L. seed extract } \\
\cline { 2 - 5 } & $200 \mathrm{mg} / \mathrm{kg}$ & $400 \mathrm{mg} / \mathrm{kg}$ & $200 \mathrm{mg} / \mathrm{kg}$ & $400 \mathrm{mg} / \mathrm{kg}$ \\
\hline $\mathrm{HE}$ & $288.00 \pm 1.67$ & $270.06 \pm 1.52$ & $253.00 \pm 2.09$ & $277.00 \pm 1.34$ \\
DCME & $95.16 \pm 1.22$ & $125.26 \pm 1.22$ & $130.63 \pm 0.40$ & $144.14 \pm 1.29$ \\
EAE & $198.56 \pm 2.97$ & $159.40 \pm 1.78$ & $200.56 \pm 1.13$ & $129.64 \pm 2.12$ \\
ME & $99.11 \pm 2.01$ & $121.51 \pm 1.69$ & $128.16 \pm 3.17$ & $162.19 \pm 2.34$ \\
Control & \multicolumn{2}{c}{ Control (placebo) } & \multicolumn{2}{c}{$280.21 \pm 2.67$} \\
Standard & \multicolumn{2}{c}{$83.33 \pm 3.33$} \\
\hline
\end{tabular}

Data are expressed as mean \pm SD (n=3). HE: $n$-hexane extract, DCME: dichloromethane extract, EAE: ethyl acetate extract, ME: methanol extract.

Table 2. Central analgesic activity of stem extract of $A$. sowa in tail immersion test.

\begin{tabular}{|c|c|c|c|c|c|c|c|c|}
\hline \multirow{4}{*}{ Sample } & \multicolumn{8}{|c|}{ Analgesic activity (A. sowa L. stem) } \\
\hline & \multicolumn{8}{|c|}{ (reaction time in second) } \\
\hline & \multicolumn{4}{|c|}{$200 \mathrm{mg} / \mathrm{kg}$ bw } & \multicolumn{4}{|c|}{$400 \mathrm{mg} / \mathrm{kg} \mathrm{bw}$} \\
\hline & $0 \mathrm{~min}$ & $30 \mathrm{~min}$ & $60 \mathrm{~min}$ & $90 \mathrm{~min}$ & $0 \mathrm{~min}$ & $30 \mathrm{~min}$ & $60 \mathrm{~min}$ & $90 \min$ \\
\hline $\mathrm{HE}$ & $3.7 \pm 0.09$ & $3.9 \pm 1.26$ & $3.9 \pm 0.45$ & $4.2 \pm 0.87$ & $3.4 \pm 1.11$ & $4.1 \pm 1.65$ & $4.1 \pm 1.65$ & $3.9 \pm 1.78$ \\
\hline DCME & $4.2 \pm 1.34$ & $4.0 \pm 1.09$ & $3.8 \pm 1.55$ & $4.1 \pm 1.13$ & $3.8 \pm 1.30$ & $3.9 \pm 1.04$ & $3.9 \pm 1.04$ & $4.1 \pm 1.23$ \\
\hline EAE & $5.2 \pm 1.31$ & $6.1 \pm 0.38$ & $5.9 \pm 1.02$ & $6.6 \pm 1.11$ & $4.6 \pm 0.79$ & $5.1 \pm 1.12$ & $5.2 \pm 1.45$ & $5.8 \pm 1.13$ \\
\hline $\mathrm{ME}$ & $3.1 \pm 0.85$ & $3.9 \pm 1.01$ & $4.0 \pm 0.39$ & $4.5 \pm 1.80$ & $4.1 \pm 1.31$ & $5.9 \pm 0.43$ & $6.3 \pm 1.25$ & $6.6 \pm 0.91$ \\
\hline \multicolumn{5}{|c|}{ Control (placebo) } & $3.0 \pm 2.33$ & $3.2 \pm 0.67$ & $3.1 \pm 1.45$ & $2.8 \pm 1.52$ \\
\hline \multicolumn{5}{|c|}{ Standard (1 mg/kg Diazepam) } & $3.3 \pm 1.67$ & $10.7 \pm 2.54$ & $9.6 \pm 0.33$ & $10.0 \pm 0.27$ \\
\hline
\end{tabular}

Data are expressed as mean $\pm \mathrm{SD}(\mathrm{n}=3)$.

Table 3. Central analgesic activity of seed extract of $A$. sowa in tail immersion test.

\begin{tabular}{|c|c|c|c|c|c|c|c|c|}
\hline \multirow{4}{*}{ Sample } & \multicolumn{8}{|c|}{ Analgesic Activity (Anethum Sowa L. Seed) } \\
\hline & \multicolumn{8}{|c|}{ (reaction time in second) } \\
\hline & \multicolumn{4}{|c|}{$200 \mathrm{mg} / \mathrm{kg}$ bw } & \multicolumn{4}{|c|}{$400 \mathrm{mg} / \mathrm{kg} \mathrm{bw}$} \\
\hline & $0 \mathrm{~min}$ & $30 \mathrm{~min}$ & $60 \mathrm{~min}$ & $90 \mathrm{~min}$ & $0 \mathrm{~min}$ & $30 \mathrm{~min}$ & $60 \mathrm{~min}$ & $90 \mathrm{~min}$ \\
\hline $\mathrm{HE}$ & $4.3 \pm 1.66$ & $5.5 \pm 1.35$ & $6.1 \pm 2.08$ & $3.3 \pm 0.52$ & $5.4 \pm 1.29$ & $5.7 \pm 0.44$ & $5.8 \pm 1.11$ & $6.9 \pm 0.66$ \\
\hline DCME & $2.9 \pm 0.68$ & $3.5 \pm 1.84$ & $4.9 \pm 1.52$ & $6.1 \pm 1.44$ & $3.7 \pm 1.29$ & $6.5 \pm 1.41$ & $7.1 \pm 1.55$ & $6.9 \pm 1.33$ \\
\hline EAE & $3.8 \pm 0.47$ & $5.9 \pm 1.23$ & $6.3 \pm 1.81$ & $7.9 \pm 1.82$ & $4.4 \pm 1.29$ & $5.9 \pm 1.09$ & $6.3 \pm 0.29$ & $7.5 \pm 1.56$ \\
\hline ME & $4.4 \pm 1.90$ & $5.9 \pm 1.11$ & $7.9 \pm 0.45$ & $8.5 \pm 1.58$ & $4.4 \pm 1.29$ & $7.0 \pm 1.08$ & $7.4 \pm 1.66$ & $7.9 \pm 1.51$ \\
\hline \multicolumn{5}{|c|}{ Control (Placebo) } & $3.0 \pm 2.33$ & $3.2 \pm 0.67$ & $3.1 \pm 1.45$ & $2.8 \pm 1.52$ \\
\hline \multicolumn{5}{|c|}{ Standard (1 mg/kg Diazepam) } & $3.3 \pm 1.67$ & $10.7 \pm 2.54$ & $9.6 \pm 0.33$ & $10.0 \pm 0.27$ \\
\hline
\end{tabular}


Table 4. Anti-diarrheal activity (in terms of \% inhibition) of $A$. sowa.

\begin{tabular}{lcccc}
\hline \multirow{2}{*}{ Sample } & \multicolumn{4}{c}{ Antidiarrhoeal activity ( number of spots after 4 hours) } \\
\cline { 2 - 5 } & \multicolumn{2}{c}{ Anethum sowa L. stem } & \multicolumn{3}{c}{ Anethum sowa L. seed } \\
\cline { 2 - 5 } & $200 \mathrm{mg} / \mathrm{kg} \mathrm{bw}$ & $400 \mathrm{mg} / \mathrm{kg} \mathrm{bw}$ & $200 \mathrm{mg} / \mathrm{kg} \mathrm{bw}$ & $400 \mathrm{mg} / \mathrm{kg} \mathrm{bw}$ \\
$\mathrm{HE}$ & 26 & 28 & 19 & 21 \\
DCME & 22 & 19 & 33 & 29 \\
EAE & 17 & 14 & 26 & 19 \\
ME & 23 & 18 & 16 & 35 \\
Control & $1 \mathrm{ml} \mathrm{Caster} \mathrm{Oil} \mathrm{as} \mathrm{emulsion}$ & & 11 & \\
Standard & $66.67 \mu \mathrm{g} / \mathrm{kg}$ (Loperamide) & &
\end{tabular}

Table 5. Anti-depressant activity of $A$. sowa in thiopental sodium induced sleeping time test.

\begin{tabular}{|c|c|c|c|}
\hline \multirow{3}{*}{ Sample } & \multirow{3}{*}{ Concentration } & \multicolumn{2}{|c|}{ Thiopental sodium induced sleeping time } \\
\hline & & \multicolumn{2}{|c|}{ (minutes) } \\
\hline & & Anethum sowa L. stem & Anethum sowa L. seed \\
\hline $\mathrm{HE}$ & $400 \mathrm{mg} / \mathrm{kg} \mathrm{bw}$ & $220.49 \pm 1.55$ & $175.39 \pm 1.46$ \\
\hline DCME & $400 \mathrm{mg} / \mathrm{kg}$ bw & $200.44 \pm 0.95$ & $195.35 \pm 1.56$ \\
\hline EAE & $400 \mathrm{mg} / \mathrm{kg}$ bw & $153.65 \pm 2.76$ & $211.66 \pm 0.98$ \\
\hline ME & $400 \mathrm{mg} / \mathrm{kg}$ bw & $177.79 \pm 2.09$ & $125.89 \pm 1.14$ \\
\hline \multicolumn{2}{|c|}{ Standard (1 mg/kg diazepam) } & $283.67 \pm 1.19$ & \\
\hline
\end{tabular}

In thiopental sodium induced sleeping time test, significant anti-depressant activity was observed at a dose of $400 \mathrm{mg} / \mathrm{kg}$ body weight as compared to the standard drug in case of HE extract of stem.

\section{Conclusion}

The seed and stem extracts of $A$. sowa have been found to be effective in pain, diarrhea and depression. Further extensive studies are needed to isolate the bioactive compounds and to investigate the underlying mechanisms for these bioactivities.

\section{References}

Al-Mansur, M. A. ,Saha, K., Sultana, N. and Siddiqi, M.M.A. 2016. Comparative studies on cytotoxic, antibacterial and antioxidant activity among different extracts of seed and stem of Anethumsowa L. available in Bangladesh. World J. Pharm. Res. 5, 110.

Ali, P., Amir, F.,Golbarg, G. and Peyman, M. K. 2010. Analgesic and Anti-inflammatory Activity of Teucriumchamaedrys leaves aqueous extract in male rats. Iranian J. Basic Med. Sci. 13,119-125.
Aydin, S., Demir, T., Ozturk, Y. and Baser, K.H. 1999. Analgesic activity of Nepetaitalica L. Phytother. Res. 13, 20-23.

Ashraf, M.A., Khatun, A., Sharmin, T., Mobin, F., Tanu, A.R.,Morshed, T., Fakir, T.A., Begum, R.A. and Nabi, A.N.2014. MPDB 1.0: a medicinal plant database of Bangladesh. Bioinformation 10, 384-386.

Agbor, G.A., Longo, F., Makong, E.A. and Tarkang, P.A. 2014. Evaluation of the antidiarrheal and antioxidant properties of Justicia hypocrateriformis. Pharm. Biol. 52, 1128- 1133.

Banglapedia. 2012. Garden Flowers. National Encyclopedia of Bangladesh (online edition).

Birmaher, B.1., Ryan, N.D., Williamson, D.E., Brent, D.A. and Kaufman, J. 1996. Childhood and adolescent depression: a review of the past 10 years. Part II. J. Am. Acad. Child Adolesc. Psychiatry. 35, 1575-83.

Duarte, I.D., Nakamura, M. and Ferreira, S.H. 1988. Participation of the sympathetic system in acetic acidinduced writhing in mice. Braz. J. Med. Biol. Res. 21, 341-343.

Greenbargena, N.J., Arwanitakis, C., Hurwitz, A. and Azarnoff, D.L. 1978. In Drug Development of Gastrointestinal Disorders, (eds.), Chirchill Livingston, New York, pp. 155- 156. 
Harris, N.C. and Ryall, R.W. 1988. Mustard oil excites but does not inhibit nociceptive dorsal horn neurones in the rat: a presumed effect on A-delta fibres. $\mathrm{Br} . J$. Pharmacol. 94, 180-184.

Horton, E.W., Main, I.H.M., Thampson, C.J. and Wright, P.M., 1968. Effect of orally administered, PCG on gastro secretion and gastrointestinal motility in man. Gut. 9, 291- 295.

Kaushik, D., Kumar, A., Kaushik, P. and Rana, A.C. 2012. Analgesic and anti-inflammatory activity of PinusroxburghiiSarg. Adv. Pharmacol. Sci. 245-431.

Li, J., Wu, X.L., Chen, Y., Tang, Z., Xu, Y.H., Jiang, J.M., Gu, Y.Y., Chen, J.P., Yang, D.P. and Wang, D.M. 2013. Antidiarrheal properties of different extracts of Chinese herbal medicine formula Bao-Xie-Ning. $J$. Integr. Med. 11, 125-134.

Pierce, N.F., Carpenter, C.C.J., Elliot, H.Z. and Greenough, W.B. 1971. Effect of protaglandins, theohylline and cholera exotoxine upon transmucosal water and electrolyte movement in canine jejunum. Gastroenterology, 60, 22-32.

Su, S., Hua, Y., Wang, Y., Gu, W., Zhou, W., Duan, J.A., Jiang, H., Chen, T. and Tang, Y. 2012. Evaluation of the anti- inflammatory and analgesic properties of individual and combined extracts from Commiphoramyrrhaand Boswelliacarterii. J. Ethnopharmacol. 139, 649-656.

Sebai, H., Jabri, M.A., Souli, A., Rtibi, K., Selmi, S., Tebourbi, O., El-Benna, J. and Sakly, M. 2014. Antidiarrheal and antioxidant activities of chamomile (Matricariarecutita L.) decoction extract in rats. $J$. Ethnopharmacol. 152, 327-332.

Shastry R., Sharma A., Sayeli V andDinkar US. 2017. Screening of antidepressant activity of punicagranatum in mice. Pharmacog J. 9, 27-29.
Sikder, M.A., Rashid, R.B., Islam, F., Hossian, A.K.M.N., Siddique, A.B., Kabir, S., Haque, M.R., Rahman, M.S. and Rashid, M.A. 2013. Screening of ten medicinal plants of Bangladesh for analgesic activity on Swiss- albino mice. Orient. Pharm. Exp. Med. 13, 327-332.

Subramanian, G., Meyyanathan, S.N., Karthik, Y., Karunakaranair, A. and Palanisamy, D.S. 2014. Development and validation of HPLC method for the simultaneous estimation of quercetin and rutin in Aganosmadichotoma (Roth) K. Schum. Int. J. Pharm. Sci. 6, 606-608.

Yu, C.H., Tang, W.Z., Peng, C., Sun, T., Liu, B., Li, M., Xie,X.F. and Zhang, H. 2012. Diuretic, antiinflammatory and analgesic activities of the ethanol extract from Cynoglossum lanceolatum. J. Ethnopharmacol. 139, 149-154.

Yao, W.R., Wang, H.Y., Wang, S.T., Sun, S.L., Zhou, J. and Luan, Y.Y. 2011. Assessment of the antibacterial activity and the antidiarrheal function of flavonoids from bayberry fruit. J. Agric. Food Chem. 59, 53125317.

Zavala-Mendoza, D., Alarcon-Aguilar, F.J., PerezGutierrez, S., Escobar-Villanueva, M.C. and ZavalaSanchez, M.A. 2013. Composition and antidiarrheal activity of Bidensodorata Cav. Evid. Based Complement. Alternat. Med. 170-290.

Zubair, K. L., Farhina, R. L., Mir, M. A. M. and Sariful I. H. 2015. Antidiarrhoeal activity and total tannin content of ethanolic leaf extract of Codiaeumvariegatum. Dhaka Univ. J. Pharm. Sci. 14, 87-90. 